\title{
LICHEN INVENTORY OF THE CROOKED LAKE FEN NATURE SANCTUARY
}

BERNARD DE VRIES, 29 Hogan Place, White City, Saskatchewan, SK S4L 1C1

\section{Introduction}

The Crooked Lake Fen Nature Sanctuary was acquired by Nature Saskatchewan in 1988. It is an excellent example of a slope seepage fen, an uncommon habitat in Saskatchewan. The nature sanctuary protects rare vegetation and attracts birds in migration. ${ }^{8}$ The fen was recognized by listing it under the International Biological Programs as the I.B.P. Area 71-3. ${ }^{2}$ A detailed survey of the Crooked Lake Fen avifauna and vascular plant vegetation was done in 1995, however, no documentation of the lichens was done at that time. ${ }^{6}$ To fill in this gap, Nature Saskatchewan suggested the need for a lichen survey of the nature sanctuary. The present paper presents the results of this survey.

The Crooked Lake Fen Sanctuary is about $4.5 \mathrm{~km}$ west of Crooked Lake at the junction of Highway 47 from Grenfell north to Melville, and Highway 247 east to Crooked Lake in the Qu'Appelle Valley. The sanctuary lies within the NW 1/4 section of $19-19-6$ - W2, in the Rural Municipality of Grayson \# 148, and is smaller than 20 hectares in total area. ${ }^{6,8}$

The sanctuary shares a large number of arboreal lichen species with the adjoining, heavily-wooded Qu'Appelle Valley coulees and upland mixed deciduous tree stands. This is not surprising, considering the climatic and physiographic similarity and continuity between the Crooked Lake Fen hardwood forest and these areas.
The area falls within the Melville Plain landscape area of the Aspen Parkland Ecoregion in the Prairie Ecozone. 'The ecological land classification units include a hardwood forest consisting mainly of Manitoba Maple (Acer negundo var. interius) (Fig.1), Balsam Poplar (Populus balsamifera) and Trembling Aspen (Populus tremuloides) intermixed with shrubs such as Choke Cherry (Prunus virginiana), Round-leaved Hawthorn (Crataegus rotundifolia), Saskatoon (Amelanchier alnifolia), and a small grassland remnant mostly surrounded by Trembling Aspen and tall shrubs (Fig. 2). Numerous wetlands with a typical wetland or marsh flora, scattered River Birch (Betula occidentalis) and willow (Salix species) make up the remainder of the sanctuary.

\section{Methodology}

Field work was done on May 13 and June 7, 2002. The existing ecological land classification was used to facilitate finding prospective lichen sites. ${ }^{6}$ Ten of the 20 ecological land classifications units were lichenologically investigated (Map 1). They are Hardwood Forest unit \# 1; Grassland unit \# 2; Trembling Aspen Bluff unit \# 3; Wet Marsh unit \# 5 with some River Birch; Dry Marsh Edge unit \# 7; Wet Meadow unit \# 8 with dominant River Birch; Wet Drainage Corridor unit \#9 with River Birch and Willow (Fig. 3); River Birch Stand unit \# 14; Manitoba Maple Forest unit \# 16 and Tall Shrub unit \# 17. The remaining units (\# 4, 6, 10-13, 15, 18-20), are marsh, wet 


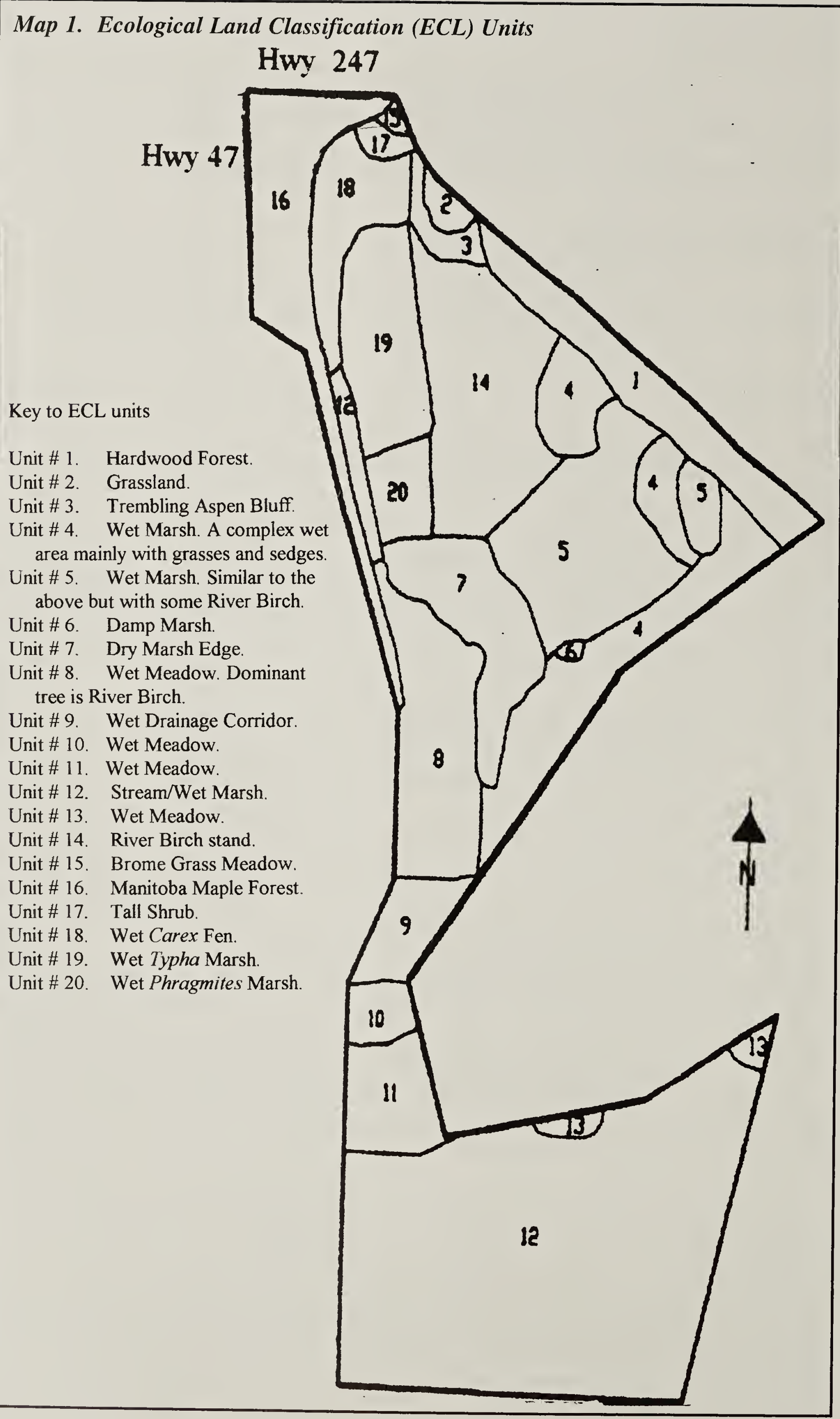




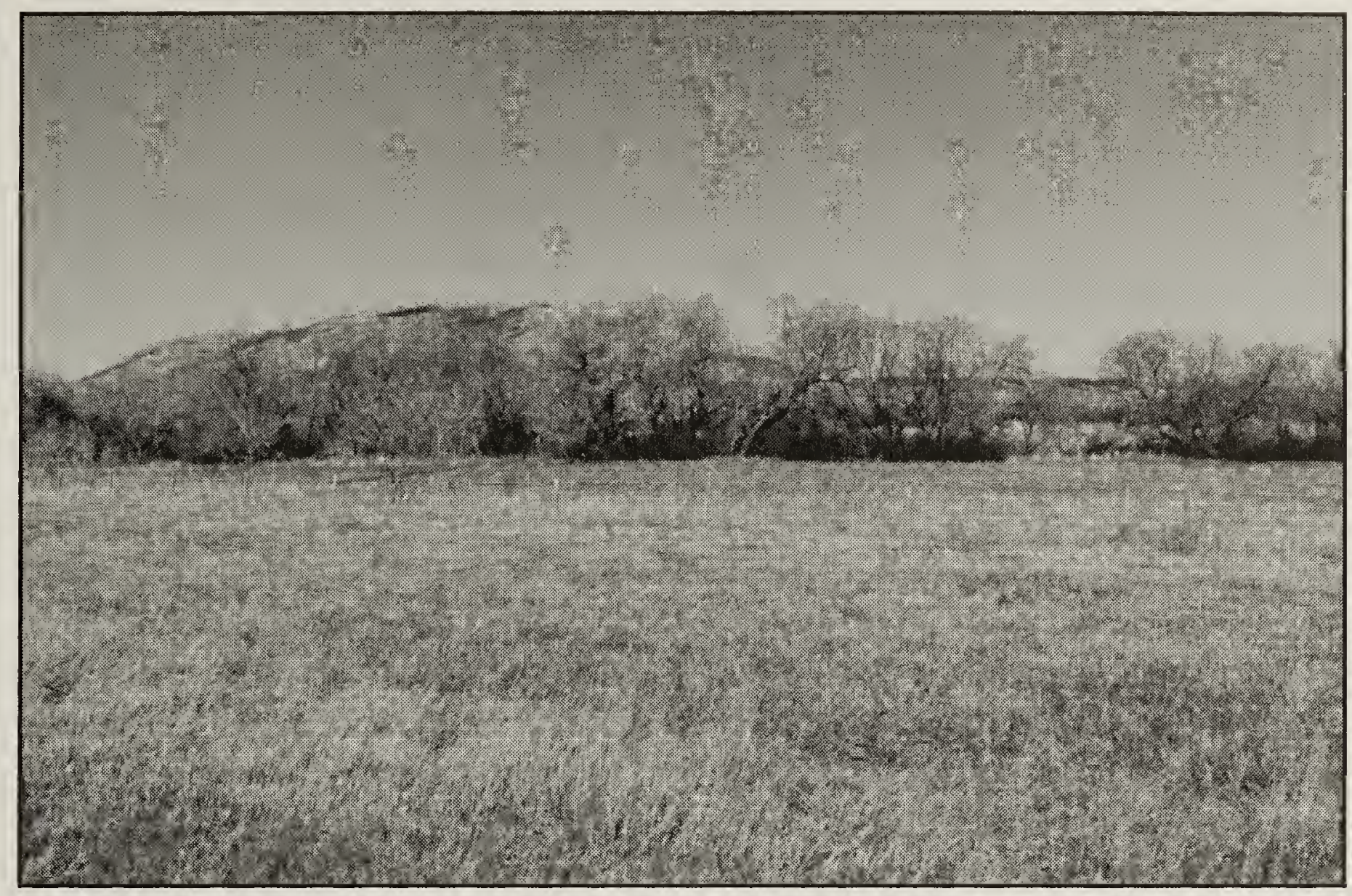

Figure 1. Manitoba Maple Forest (ELC Unit \# 16)

Bernard de Vries

meadow, and stream/wet marsh mainly vegetated with grasses such as Reed Grass (Calamagrostis species) and Common Reed Grass (Phragmites communis ), Common Cattail (Typha latifolia), and sedges (Carex species). These areas are prone to periodic flooding, with scanty tree and shrub vegetation-conditions not well suited to lichen growth.

A random survey was done to select trees and tall shrubs representative of their respective ecological land classification and substratum. The lichen survey of the grassland remnant was done by a careful search for terrestrial lichens within a grid pattern, rather than a random survey, as grassland lichens are generally very small and ground hugging, thus easily overlooked among grasses.

The investigation of tree lichens was restricted to species appearing on the lower part of trunks, up to a height of $2.50 \mathrm{~m}$ above ground. However, in a few cases lichens were collected from large branches within this range. Lichens on small twigs, branches or on trunks above $2.50 \mathrm{~m}$ have been omitted from the investigation. This method allowed for more homogeneous and comparable environmental conditions. However, tree lichens were at times collected as ground litter, and regarded as wind-blow from the adjacent hardwood stands.

Standard methods were used for identification, including technical key manuals, chemical spot testing with $10 \%$ $\mathrm{KOH}$ aqueous solution or bleach (C) to observe different colour reactions with chemicals in the lichen body (thallus), and occasionally dissecting of fruiting bodies (apothecia) to observe spore morphology and number under high magnification. ${ }^{3}$

\section{Lichen flora}

The known lichen flora of Crooked Lake Fen consists of 22 species within 13 genera. The small number of species is not surprising as the areas investigated are small, but the lichens made up for the small number of species by their quantity and dispersal throughout the nature preserve, often showing colourful patches on host trees especially some Xanthoria species 
(Sunburst lichens). No new additions to the known Saskatchewan lichen flora were found (de Vries, Lichens of Saskatchewan, in preparation).

The lichens recorded are Pan Temperate in distribution and belong to the Aspen Prairie Ecoregion of the Prairie Ecozone. ${ }^{3}$ They are comparable to lichens found on wooded slopes and in coulees, or on grassland slopes in the Qu'Appelle Valley, which also falls within this Ecoregion.

\section{Of special interest was Evernia} mesomorpha (Boreal oakmoss lichen) and Ramalina cfr. dilacerata (Punctured ramalina) associated with Physcia adscendens (Hooded rosette lichen), Physcia stellaris (Star rosette lichen), Physconia detersa (Bottlebrush frost lichen).These species were growing on a deciduous twig found as ground litter at the base of a small knoll in grassland unit \# 2 and speculated to have been blown in from adjacent hardwood stands in units \# 1, 3 and 17. The last three species occur on a variety of trees in these stands; however, we failed to locate Evernia mesomorpha and Ramalina cfr. dilacerata in these units or other areas investigated in the nature sanctuary.

Evernia mesomorpha and Ramalina cfr. dilacerata are unusual species in the Nature Sanctuary, and although Evernia mesomorpha is a common species in the boreal forest on deciduous as well as on coniferous trees, and previously was found in the Qu'Appelle Valley on an old weathered wooden fence (de Vries, unpublished), the species remains uncommon in the Aspen Parkland Prairie Ecoregion. Ramalina cfr. dilacerata which is a typical boreal species is really not expected this far south, and could be considered as rare. How this species arrived in the nature sanctuary remains a mystery.

The majority of lichens at Crooked Lake Fen are tree lichens (arboreal). Mature
Manitoba Maple, American Elm (Ulmus americana) and Balsam Poplar in the hardwood forest stands of units \# 1, 3, and 16 show the most diversified lichen flora with Caloplaca holocarpa (Firedot lichen), Candelariella vitellina (Common goldspeck lichen), Physcia adscendens (Hooded rosette lichen), Physcia stellaris (Star rosette lichen), Xanthoria fallax (Hooded sunburst lichen), and Xanthoria polycarpa (Pin-cushion sunburst lichen) as common and often showy species well dispersed throughout the sanctuary. These older trees provide a greater variety of microhabitats, allowing many different types of lichens to colonize. Their rough and stable bark has the ability to absorb and retain moisture, besides having organic and chemical compounds necessary for lichen metabolism. In contrast, Trembling Aspen and River Birch have a relative smooth bark that cannot absorb or retain sufficient moisture and support lichen species which have more or less adapted to such substrate. Less common arboreal lichens in the hardwood units are: Candelaria concolor (Lemon lichen), Flavopunctelia flaventior (Speckled greenshield), Parmelia sulcata (Hammered shield lichen), and Xanthoria candelaria (Shrubby sunburst lichen).

Terrestrial lichens occur only in the grassland on light mineral soil mostly under dead grass-litter. This is somewhat unusual, as these lichens generally prefer areas free from competitive vegetation. Cladonia (Cladonia lichen) was the dominant genus with such common and typical grassland species as Cladonia pocillum (Rosette pixie-cup) and Cladonia pyxidata (Pebbled pixie-cup). Cladina mitis (Green reindeer lichen) a more typically boreal species occurs in the grassland area, and sporadically in the Prairie Ecozone on sandy or humus soils. Not surprisingly Peltigera rufescens (Field dog-lichen), a common lichen on dry sandy soil in open fields and roadsides, was found twice in association with Prairie Selaginella (Selaginella densa) in this grassland unit. 


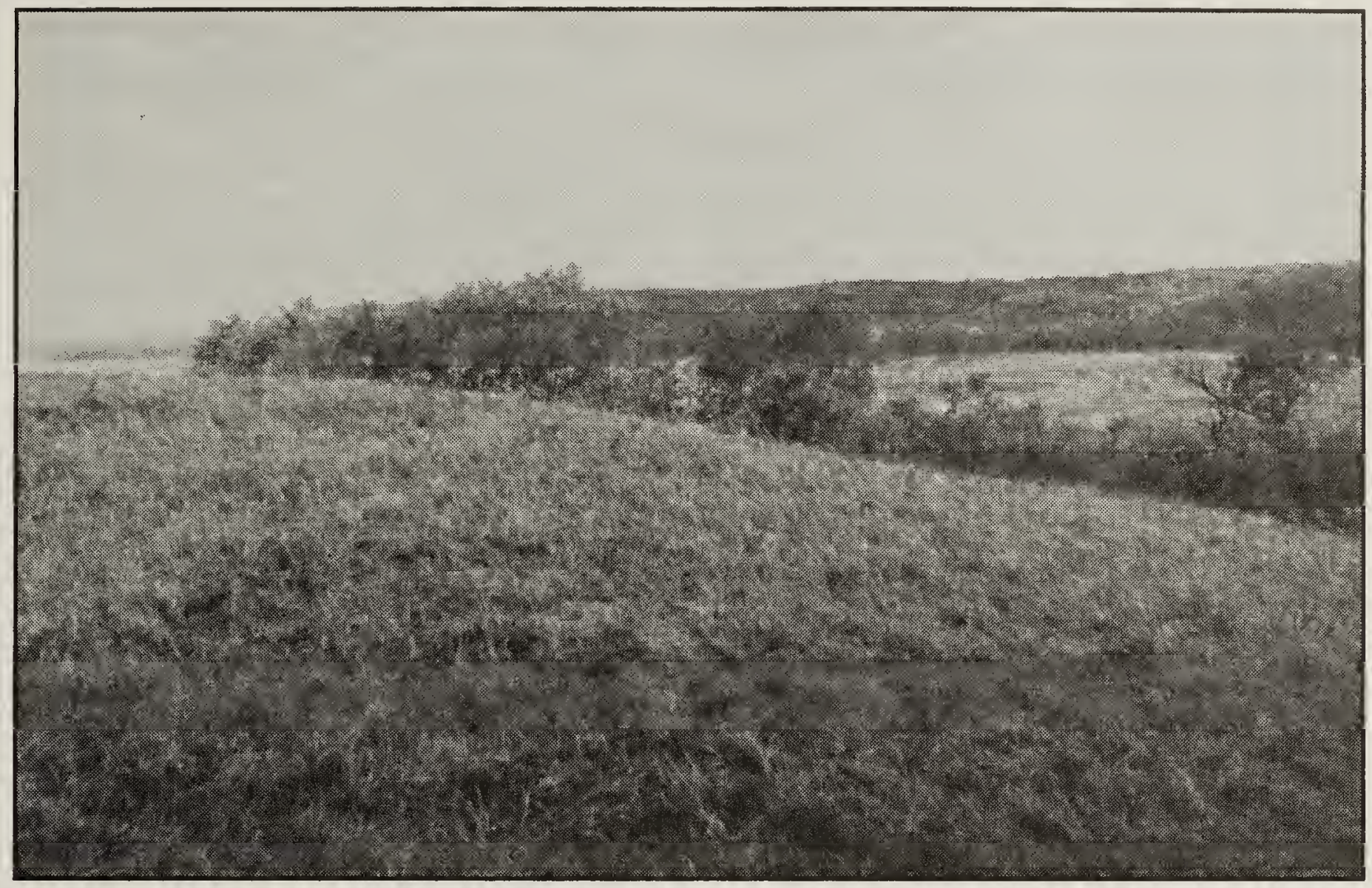

Figure 2. Grassland (ECL Unit \# 2.)

Bernard de Vries

\section{Annotated list of lichens}

The annotated list summarizes the ecological land classification unit, substrates, and occurrence. The scientific names and authors follow Esslinger, while vernacular names are those of Brodo et al., and Goward ${ }^{4,3,7}$

Some lichens were field identified; voucher specimens of collected material are deposited in the author's private herbarium.

\section{Caloplaca (Firedot lichens)}

Caloplaca cerina (Ehrh. ex Hedwig) Th. Fr. (Gray-rimmed firedot lichen). An infrequent bark dwelling lichen on Manitoba Maple and at times on Balsam Poplar in units \# 1 \& 16, often among Caloplaca holocarpa.

Caloplaca holocarpa (Hoffm. ex Ach.) Wade ( Firedot lichen). A common lichen found on rough bark and old wood of many trees and occasionally on tall shrubs in units \# 1, 3, 5, 14, 16, 17.

Candelaria (Candleflame lichens)

Candelaria concolor (Dickson) Stein
(Lemon lichen). Infrequent on smooth bark of Choke Cherry, Round-leaved Hawthorn and River Birch in units \# 1, 14, \& 17. Also occasionally occurring on rough bark of Manitoba Maple in units \# 1 \& 16.

\section{Candelariella (Goldspeck lichens)}

Candelariella vitellina (Hoffm.) Th.Fr. (Common goldspeck lichen). Common locally on rough bark of Manitoba Maple in units \# 1 \& 16. Infrequent on rough bark of Balsam Poplar in unit \# 1.

\section{Cladina (Reindeer Lichens)}

Cladina mitis (Sandst.) Hustich (Green reindeer lichen). Unusual, and found once in Grassland unit \#2 on light soil with Prairie Selaginella.

\section{Cladonia (Cladonia lichens)}

Cladonia chlorophaea (Floerke ex Sommerf.) Sprengel (Mealy pixie-cup). Infrequent in Grassland unit \# 2 on light soil. Mainly under grass litter and with other Cladonia species.

Cladonia decorticata (Floerke) Sprengel (Perlatolic pebblehorn). Infrequent in 
Grassland unit \# 2 on light soil with Prairie Selaginella and other Cladonia species.

Cladonia pocillum (Ach.) Grognot (Rosette pixie-cup). Common in Grassland unit \# 2 on light soil with Cladonia chlorophaea and Cladonia pyxidata under grass litter.

Cladonia pyxidata (L.) Hoffm. (Pebbled pixie-cup). Common in Grassland unit \# 2 on light soil with Cladonia chlorophaea, Cladonia pocillum and Prairie Selaginella.

Cladonia rei Schaerer (Wand lichen). Uncommon in Grassland unit \# 2 on light soil under grass litter with other Cladonia species.

\section{Evernia (Oakmoss lichens)}

Evernia mesomorpha Nyl. (Boreal oakmoss lichen). Uncommon, and found only once, on a small twig as ground litter with Physcia adscendens, Physcia stellaris, Physconia detersa, and Ramalina cfr. dilacerata in Grassland unit \# 2.

Flavopunctelia (Speckled greenshield lichen)

Flavopunctelia flaventior (Stirton) Hale (Speckled greenshield). Uncommon on rough bark of mature Green Ash (Fraxinus pensylvanica) in unit \# 1.

\section{Parmelia (Shield lichens)}

Parmelia sulcata Taylor (Hammered shield lichen). Uncommon on smooth bark of Choke Cherry in Hardwood Forest unit \# 1 and Tall Shrub unit \# 17.

\section{Peltigera (Pelt lichens)}

Peltigera rufescens (Weiss.) Humb. (Field dog-lichen). Uncommon, and found twice on soil among grasses and Prairie Selaginella in Grassland unit \#2.

\section{Physcia (Rosette lichens)}

Physcia adscendens (Fr.) H. Oliver (Hooded rosette lichen). Common on rough bark of Green Ash and Manitoba Maple, and infrequent on smooth bark of Choke Cherry and Round-leaved Hawthorn in units \# 1 \& 17. Also occurring with Evernia mesomorpha, Physcia stellaris, Physconia detersa, and Ramalina cfr. dilacerata on a twig as ground litter in Grassland unit \# 2.

Physcia aipolia (Erh. ex Humb.) Fuernr var. aipolia ((Hoary rosette lichen). Quite common on rough bark of Manitoba Maple, American Elm and Balsam Poplar in units \# $1,3,16$.

Physcia stellaris (L.) Nyl. (Star rosette lichen). Frequent on rough bark of mature Manitoba Maple, Balsam Poplar and Green Ash, and infrequent on smooth bark of River Birch; Choke Cherry, Round leaved Hawthorn and some dead standing tall shrubs or trees in units \# 1, 3, 5, 8, 9,14,16, \& 17. Also found with Evernia mesomorpha, Physcia adscendens, Physconia detersa and Ramalina cfr. dilacerata on a small twig as ground litter in Grassland unit \# 2.

\section{Physconia (Frost lichen)}

Physconia detersa (Nyl.) Poelt (Bottlebrush frost lichen). Infrequent on rough bark of Manitoba Maple and Green Ash, and on smooth bark of Choke Cherry and Round leaved Hawthorn in units \# 16 \& 17. Also found with Evernia mesomorpha, Physcia adscendens, Physcia stellaris and Ramalina cfr. dilacerata on a small twig as ground litter in Grassland unit \# 2.

\section{Ramalina (Ramalina lichens)}

Ramalina cfr. dilacerata (Hoffm.) Hoffm. (Punctured ramalina). Rare. Found once as an immature specimen on a small twig as ground litter in Grassland unit \# 2 with Evernia mesomorpha, Physcia adscendens, Physcia stellaris and Physconia detersa.

\section{Xanthoria (Sunbust lichens)}

Xanthoria candelaria (L.) Th. Fr. (Shrubby sunburst lichen). Infrequent on rough bark and old branches of mature Manitoba Maple in unit \# 16. 


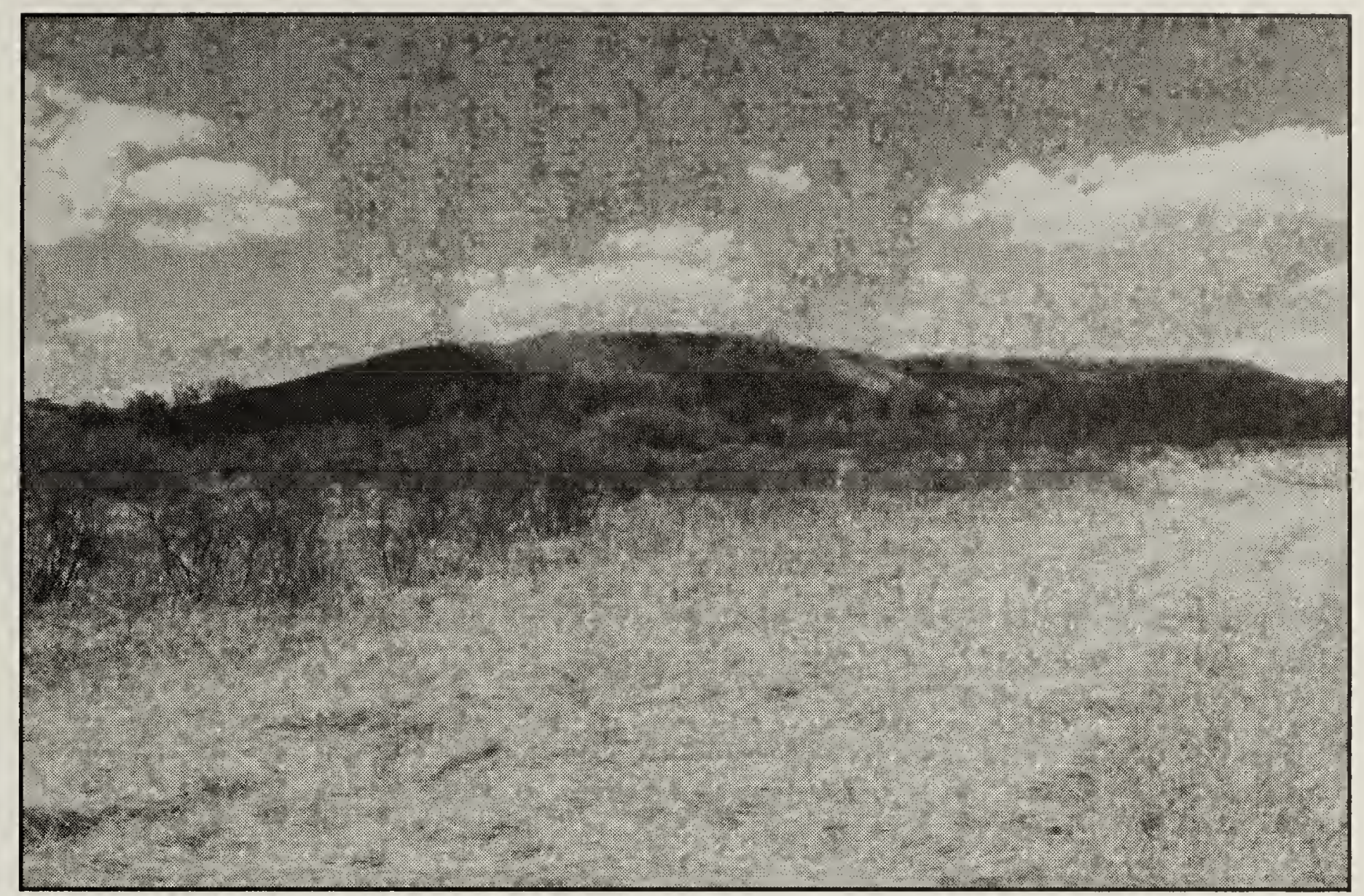

Figure 3. Wet prairie corridor with Hoary Willow and River Birch (ECL\# 9)

Bernard de Vries

Xanthoria fallax (Hepp.) Arnold var. fallax (Hooded sunburst lichen). Common on rough bark of various trees and relatively frequent on smooth bark of tall shrubs in units \# 1, 3, 5, 9,14, 16, \& 17.

Xanthoria polycarpa (Hoffm.) Rieber (Pin-cushion sunburst lichen). Common on a variety of substrates, mainly on rough bark, old branches and twigs of trees and smooth bark of shrubs in units \# $1,3,8,14$, $16, \& 17$. Also found growing on a small rock in grassland Unit \# 2, and as a small specimen on a willow in unit \# 7 .

\section{Discussion}

In the nature sanctuary, the age of trees tends to increase from the younger trees on the periphery to the older trees in the centre of larger forest stands. A decline in lichen diversity in the centre of the stands could partially be explained by the lower light intensity under a closed canopy of mature trees. The absence of terrestrial lichens in the hardwood vegetation units could partially be due to a dense shrub and herb understory which is a deterrent to terrestrial lichen development. As trees die, they create openings and habitat for renewed lichen growth.

No previous documentation of the lichens has been done for Crooked Lake Fen. This survey presents a first, augmenting our present knowledge of the vascular flora in this Nature Sanctuary by adding 22 lichen species including two species which being unusual (Evernia mesomorpha) or even rare (Ramalina cfr. dilacerata), add value to this unique area. Although some lichen species might have been overlooked, the present survey gives a fair picture of species existent in the Sanctuary.

The proximity of arable land east and west of the Nature Sanctuary could pose a problem due to chemical spray drift. Because a survey of lichens in the marginal zone could give an indication of air quality, especially when compared to lichens in the same region, attention was given to the possibility of air pollutants affecting the lichen flora, especially on marginal trees in the nature sanctuary and adjoining areas. 
Lichens do not have a protective cuticle or roots; they absorb dissolved nutrients as well as air borne pollutants directly from the air or rainwater and are extremely sensitive to atmospheric pollution. However, insofar as we were able to observe, there was no visible damage to lichens from pollution in the nature sanctuary or in the adjoining areas. The impending changing climatic patterns causing a dramatic shifting of ecosystems could be a more imminent danger.

\section{Acknowledgements}

We are much indebted to SaskEnergy, Regina for generously funding the Crooked Lake Fen lichen survey. Thanks are also due to Nature Saskatchewan for initiating this lichen study. Without this support this survey would not be possible. Thanks are also due to Diether Peschken for helpful suggestions on the first draft of this paper. Last but not least thanks are due to my wife Irma, who braved mosquitoes and ticks in the name of science and whose keen eye added many a lichen to the list.

1. ACTON, D. F., G. A. PADBURY, and C. T. STUSHNOFF. 1998. The Ecoregions of Saskatchewan. Canadian Plains Research Center. University of Regina, Regina.

2. ADAM, C.I.G. 1985. Natural areas in Saskatchewan. A review of the IBP System. Prepared for the Saskatchewan Natural History Society.
3. BRODO, I. M., S. D. SHARNOFF, and S. SHARNOFF. 2001. Lichens of North America. Yale University Press. New Haven.

4. ESSLINGER, T. L. 1997. A cumulative checklist for the lichen-forming lichenicolous and allied fungi of the continental United States and Canada. North Dakota Sate University. Online: http/ /www.ndsu.nodak.edu./instruct/esslinge/ chcklst/chcklst7.htm (First Posted 1 December 1997. Most Recent Update 19 July, 1999, Fargo, North Dakota.)

5. FELSKE, D. F., and B. PEG. 1971. Crooked Lake IBP No. 71-3. IBP-CT. Check Sheet. Golder Associates Ltd. 1995. Report on Crooked Lake Fen Avifauna and Vegetation Survey. Report prepared for SaskEnergy.

6. GOLDER ASSOCIATES Ltd. 1995. Report on Crooked Lake fen avifauna and vegetation survey. Report prepared for SaskEnergy.

7. GOWARD, T. 1999. The Lichens of British Columbia. Part 2 - Fruiticose Species. Crown Publications. Victoria. British Columbia.

8. PESCHKEN, D. P. 2000. Ecological Inventory of The Crooked Lake Fen Sanctuary. Report prepared for Nature Saskatchewan. 